\title{
Lærere i naturfag som forskere. NORDLAB-DK: Det praktiske og eksperimentelle arbejde i naturfagene
}

\author{
Pedagogical changes fail when they do not engage the passions of the classroom.
}

(Hargreaves 1997)

\section{INDLEDNING}

I det følgende beskrives et udviklingsarbejde i det praktiske og eksperimentelle arbejde i naturfagene, der benytter "den forskende lærer" som model for forsknings- og udviklingarbejde og for efteruddannelse af naturfagslærere. Det drejer sig om et dansk bidrag til NORDLAB - projektet: Nordisk laboratorium for god praksis i matematik, naturfag og teknologi. Projektet blev udarbejdet af en projektgruppe for Nordisk Skolesamvirke (NSS) på baggrund af en beslutning i Nordisk Ministerråd om at stimulere udviklingen af undervisningen i matematik, naturfag og teknologi. NORDLAB - projektet kom til at bestå af fem nationale projekter med forskellige emner for hvert af de nordiske lande (Nordlab). På opfordring fra NSS iværksatte Undervisningsministeriet i Danmark et forsknings- og udviklingsprojekt om det praktiske og eksperimentelle arbejde i naturfagene. Ifølge sit idegrundlag skal NORDLAB - projektet ved at sprede bidragene fra de enkelte nordiske lande "give undervisere i matematik og naturfag mulighed for at opnå øget kundskab, bevidsthed og refleksion over egen praksis, samt bidrage til at øge deres lyst til at prøve nye ideer". Det var derfor af stor betydning, at lærere, undervisere på læreruddannelser og efteruddannelser blev direkte involveret i dette arbejde.

\section{"DEN FORSKENDE LAERER"}

"Svaret på spørgsmålet om, hvordan lærerne skal kunne ændre praksis, som konsekvens af evalueringsresultater eller nye læreplaner vil ofte fra såvel lærerside som skolesystemet være kurser med et pædagogisk indhold, men som Justin Dillon refererer (2000), er dette ikke nogen særlig effektive form for efteruddannelse. Traditionel kursusvirksomhed og workshops om nye materialer osv. er velkendte undervisningsformer i efteruddannelsen, men den praktiserende lærer har sjælden nogen medindflydelse på kursusindholdet, som ofte indebærer en tro på og en forventning om, at god praksis kan overføres fra en person til en anden. Konkret foregår pædagogisk fornyelse af praksis 
imidlertid i organisationens bund hos læreren og eleverne i klasserummet, hvor lærerens undervisning og elevers læring er afhængige af de meget forskellige forhold, som de enkelte skoler, klasser, lærere og elever er undergivet. Mens industrier kan anvende de samme processer forskellige steder i verden og levere helt ens produkter, så kan god praksis i en klasse være helt forfejlet i en anden (Guskey, 1995). Initiativerne til efteruddannelse kan derfor vise sig at være helt utilstrækkelige med ringe indflydelse på praksis.

En alternativ model til de traditionelle efteruddannelsesinitiativer er klasserumsbaserede forsknings- og udviklingsprojekter, hvor den enkelte lærer er aktør i udviklingen af undervisningspraksis og egen professionalisering. Modellen "den forskende lærer" har sit grundlag i aktionsforskningen og er en proces, hvor læreren forsker i egen praksis med henblik på at løse problemer i sin egen undervisning. Initiativer til fornyelse og ændring i den pædagogiske praksis er nær knyttet til klasserummet og til lærerens behov og praksis. Et forsknings- og udviklingsarbejde vil da i regelen være integreret i lærerens daglige undervisning og dermed også være relativt beskeden i omfang og ambitionsniveau. Hensigten er, at læreren evt. i samarbejde med kolleger får mulighed for at reflektere over og udvikle egen praksis og dermed tage hånd om sin egen professionalisering. Anden aktionsforskning foregår ofte som et samarbejde mellem en forsker og den praktiserende lærer, hvor emnet ganske vist er lærerens problemer og behov, men hvor det forskningsmæssige arbejde udføres af forskeren. Derved vil ejerskabet til forskningen og dens resultater ofte bero mere hos forskeren end hos læreren. I "den forskende lærer" er det imidlertid læreren, der tager initiativet og har ejerskabet til forskningen og dens resultater.

\section{UDVIKLINGSARBEJDET NORDLAB-DK}

\section{Principper, mål og rammer}

Det danske undervisningsministerium nedsatte en projektledergruppe ${ }^{1}$, som på grundlag af opdraget fra Nordisk Skolesamvirke og ovenstående baggrund foretog en række valg om mål, indhold og organisering af forsknings- og udviklingsprojektet NORDLAB-DK. Der blev således fokuseres på følgende tre områder:

- En undersøgelse af hvilke intentioner det praktiske og eksperimentelle arbejde i naturfagene rummer, og hvordan intentioner, praksis og elevernes læring hænger sammen.

- En udvikling af det biologiske og geografiske feltarbejde, dets didaktik og praksis, da det er et forholdsvis ringe udviklet og beskrevet undervisningsområde.

- Et klasserumsbaseret forsknings- og udviklingsarbejde gennemført i nær tilknytning til lærernes praksis, hvor lærerne selv designer og gennemfører arbejdet med henblik på at udvikle egen undervisning og professionalisme.

Resultaterne af dette arbejde skulle som et krav for hele NORDLAB - projektet kunne præsenteres og kommunikeres på en sådan måde, at de kunne være til hjælp og inspiration for andre naturfagslærere i Norden.

Målgruppen for forsknings- og udviklingsarbejdet var lærere i de naturfagene i grundskolen, på de gymnasiale uddannelser og på læreruddannelserne. Målet for forsknings- og udviklingsarbejdet blev i projektbeskrivelsen (Goldbech \& Paulsen, 2000) formuleret således:

"Forskningens generelle mål er at give såvel praktiserende som kommende lærere redskaber til at udvikle deres undervisning og ændre praksis i forbindelse med det eksperimentelle arbejde hen imod en større overensstemmelse med intentionerne."

1 Fagkonsulent Eigil Larsen (GSI), undervisningsinspektør Claus Helmann Christensen (GYA), fagkonsulent Birgitte Appel (GYE), lektor Ole Goldbech (KDAS)(projektleder) og lektor Albert Chr. Paulsen (RUC)(projektleder) 
Udviklingsarbejdet skulle udføres af selvstyrende arbejdsgrupper af praktiserende lærere med mulighed for hjælp og støtte fra fagdidaktisk forskningsekspertise efter modellen "læreren, der forsker i og udvikler sin egen undervisning". Med udgangspunkt i egne behov, interesser og muligheder skulle arbejdsgrupperne fremsende ansøgninger med projektbeskrivelser, der rummede formål, metoder, tidsplan, og budget. Resultaterne af arbejdet skulle kunne publiceres i form af workshoppapirer og spredes "fra lærer til lærer" lokalt, nationalt og i Norden, så lærere i naturfag har fri adgang til at anvende dem som hjælp og inspirationskilder til deres undervisning.

\section{Projektforløbet}

Projektet udfoldede sig dernæst i følgende organisering af projektforløbet:

1. For at informere om projektet blev der afholdt en idé - konference den 1.marts 2000 for nøglepersoner på de uddannelsesniveauer og institutioner, som var omfattet af målgruppen. Ved denne konference blev projektbeskrivelsen publiceret, og der blev givet oplæg om det praktiske arbejde, og om den aktuelle problematik, som havde givet anledning til forsknings- og udviklingsarbejdet. Deltagerne blev dernæst opfordret til i en række workshops at udforme ideer til mulige arbejder. Disse ideer blev fremlagt og diskuteret i plenum.

2. Ansøgninger blev vurderet af projektledergruppen udfra om problemstillingen var i overensstemmelse med det generelle mål, om den forskningsmæssige kvalitet kunne godkendes, og om arbejdet tidsmæssigt og økonomisk kunne gennemføres.

3. Arbejdet begyndte sommeren 2000. Arbejdsgrupperne var selvstyrende, men projektlederne ${ }^{2}$ holdt løbende kontakt og deltog på eget initiativ, eller når det var ønsket, i gruppemøder. Derudover blev der stillet fagdidaktisk ekspertise til rådighed af konsulenter og de to projektledere. I tre af grupperne deltog fagdidaktikere fra forskningsinstitutioner.

4. Midtvejs i forløbet blev arbejdsgrupperne bedt om statusrapporter, som skulle redegøre for det udførte arbejde og en plan for resten af forløbet, og den 1.februar 2001 blev der afholdt et midtvejsseminar. Hvert projekt blev her præsenteret og diskuteret i en række workshops på baggrund af forberedte spørgsmål fra en "opponentgruppe", der havde sat sig ind i gruppens statusrapport.

5. Mod slutningen af arbejdet (december 2001) blev grupperne igen bedt om statusrapporter, som blev samlet og udsendt til information for alle deltagere.

6. Projektet blev afsluttet ved, at der blev afholdt et slutseminar, hvor udvalgte projekter blev præsenteret i plenum, og hvor alle projekter blev fremlagt i workshopgrupper.

7. Alle arbejdsgrupper afleverede deres workshoppapirer i løbet 2002. De er efterfølgende blevet redigeret af projektlederne og publiceret på en hjemmeside sammen med alle bidrag med relation til NORDLAB-DK (EMU, Velkommen til temaet om Nordlab). Der er ligeledes efterfølgende publiceret en rapport over arbejdet (Goldbech \& Paulsen, 2004), som også findes på hjemmesiden. Derudover har arbejdsgrupperne selv kommunikeret deres resultater ved regionale møder, ved konferencer og i tidsskriftartikler (EMU publikationer).

Resultatet af udviklingsarbejdet blev en række workshoppapirer, af meget forskelligt art og omfang. De repræsenterer alle skoleformer og alle naturfagene. Alle bidragene (projekt1-13) kan ses på NORDLAB-DK's hjemmeside (EMU projekterne). Bidragene består blandt andet af konkrete undervisningsmaterialer, interaktive computersimuleringer (såkaldte Physlets) og undersøgelser af læreres intentioner med praktisk arbejde og elevernes fagopfattelse og læring, ligesom der er bidrag til feltarbejdets didaktik.

\footnotetext{
${ }^{2}$ Lektor Ole Goldbech, KDAS og lektor Albert Chr. Paulsen, IMFUFA. RUC
} 


\section{SAMMENFATNING OG PERSPEKTIVER}

Arbejdsgrupperne i NORDLAB-DK involverede ca. 50 lærere. Dertil kommer, at enkelte grupper inddrog yderligere andre lærere i forskellige sammenhænge i løbet af projektet. Forløbet og resultatet af projektet har bekræftet projektledelsen i, at de principper, der blev lagt til grund for NORDLAB-DK, har været frugtbare som redskab til udvikling og fornyelse af det praktiske og eksperimentelle arbejde i naturfagene. Ved at initiativet udgik fra læreren, og ved at arbejdet var en integreret del af den daglige praksis, involverede det læreren optimalt.

Erfaringerne synes at bekræfte antagelsen om, at "den forskende lærer" som en model for professionalisering af lærere i naturfag er et godt efteruddannelsesinitiativ og et alternativ til kursusundervisning. Arbejdet må for at blive udnyttet optimalt have en organisatorisk ramme udover de menneskelige ressourcer i form af engagement hos lærerne, vilje til samarbejde hos lærerne og mellem lærerne og en fagdidaktisk ekspertise, som f.eks. kan være en medarbejder ved en forskningsinstitution.

\section{REFERANSER}

Dillon, J. (2000). Managing the science department. In: Monk, M. and Osborne, J.(eds.). Good practice in science teaching. What research has to say. Buckingham, Philadelphia: Open University Press. pp. 123-38.

EMU, projekterne (u.å., opdateret 15.december 2004). Lokaliseret 9. marts 2005 på World Wide Web: http://www.nordlab.emu.dk/projekter/index.html

EMU publikationer (u.å. opdateret 21.oktober 2004). Lokaliseret 9. marts 2005 på World Wide Web: http://www.nordlab.emu.dk/projekter/index.html

EMU, Velkommen til temaet om Nordlab (u.å., opdateret 18.februar 2005). Lokaliseret 9. marts 2005 på World Wide Web: http://www.nordlab.emu.dk

Goldbech, O., Paulsen, A.C. (red.)(2000). Projektbeskrivelse. Det praktiske og eksperimentelle arbejde i naturfagene. Et forsknings- og udviklingsprojekt. Lokaliseret 9. marts 2005 på World Wide Web: http://www.nordlab.u-net.dk/www/projekt/beskr.htm

Goldbech, O. og Paulsen, A.C. (2004). NORDLAB-DK. Det praktiske og eksperimentelle arbejde $i$ naturfagene. Et forsknings- og udviklingsprojekt. Slutrapport. IMFUFA Tekst nr. 434. 2004. Roskilde. IMFUFA. Roskilde Universitetscenter. Lokaliseret marts 9, 2005 på World Wide Web: http://www.nordlab.emu.dk/rapporten/index.html

Guskey, Th. R.(1995). Professional development in Education. I: Guskey, Th. R. and Hubermann, M.: Professional development in Education. New Paradigms and Practices. New York and London: Teachers Colleges Press.

Hargreaves, A. (1997). Rethinking Educational Change: Going Deeper and Wider in the Quest for Success. Chapter 1, The Emotions of Educational Change. I: Hargreaves, A. (1997) (red): Rethinking Educational Change with Heart and Mind. ASCD Yearbook 1997.Lokaliseret marts 9, 2005 på World Wide Web: http://www.ascd.org/ portal/site/ascd/template.chapter/menuitem.ccf6e1bf6046da7cdeb3ffdb62108a0c/ ?chapterMgmtId=a9198aec2ecaff00VgnVCM1000003d01a8c0RCRD

Nordlab (u.å, opdateret 15.oktober 15.2003). Lokaliseret marts 9, 2005 på World Wide Web: http://na-serv.did.gu.se/nordlab 